\title{
Electrolyte depletion and osmotic imbalance in amphibians with chytridiomycosis
}

\author{
Jamie Voyles ${ }^{1, *}$, Lee Berger ${ }^{1}$, Sam Young ${ }^{1}$, Rick Speare ${ }^{1}$, Rebecca Webb ${ }^{1}$, \\ Jeffrey Warner ${ }^{2}$, Donna Rudd ${ }^{2}$, Ruth Campbell ${ }^{1}$, Lee F. Skerratt ${ }^{2}$
}

${ }^{1}$ Amphibian Disease Ecology Group, School of Public Health, Tropical Medicine and Rehabilitation Sciences, and ${ }^{2}$ Amphibian Disease Ecology Group, School of Veterinary and Biomedical Sciences, James Cook University, Townsville, Queensland 4811, Australia

\begin{abstract}
Mounting evidence implicates the disease chytridiomycosis, caused by the fungus Batrachochytrium dendrobatidis, in global amphibian declines and extinctions. While the virulence of this disease has been clearly demonstrated, there is, as yet, no mechanistic explanation for how $B$. dendrobatidis kills amphibians. To investigate the pathology of chytridiomycosis, blood samples were collected from uninfected, aclinically infected and clinically diseased amphibians and analyzed for a wide range of biochemical and hematological parameters. Here, we show that green tree frogs Litoria caerulea with severe chytridiomycosis had reduced plasma osmolality, sodium, potassium, magnesium and chloride concentrations. Stable plasma albumin, hematocrit and urea levels indicated that hydration status was unaffected, signifying depletion of electrolytes from circulation rather than dilution due to increased water uptake. We suggest that $B$. dendrobatidis kills amphibians by disrupting normal epidermal functioning, leading to osmotic imbalance through loss of electrolytes. Determining how $B$. dendrobatidis kills amphibians is fundamental to understanding the hostpathogen relationship and thus the population declines attributed to $B$. dendrobatidis. Understanding the mechanisms of mortality may also explain interspecific variation in susceptibility to chytridiomycosis.
\end{abstract}

KEY WORDS: Amphibian declines - Chytridiomycosis • Batrachochytrium dendrobatidis . Pathogenesis $\cdot$ Mortality $\cdot$ Osmoregulation

\section{INTRODUCTION}

Amphibians are currently undergoing the fastest rate of extinction of any vertebrate group (Stuart et al. 2004). While habitat destruction or overexploitation are obvious primary causes in some declines, determining why amphibians are experiencing catastrophic declines in protected areas has been more challenging. Amphibian mass-mortalities and declines have coincided with the appearance of the fungal pathogen Batrachochytrium dendrobatidis in wild amphibian communities (Lips et al. 2006, Berger et al. 2007). This fungus is lethal to many species of amphibians (Berger et al. 1998, 2005a, 2007, Longcore et al. 1999, Nichols et al. 2001, Lips et al. 2006), yet the mechanism by which it causes death is unknown (Berger et al. 1998, 2007). B. dendrobatidis is confined to the superficial layers of the epidermis and causes no consistent pathological changes in internal organs (Berger et al. 1998, 2007, Pessier et al. 1999). Two hypotheses as to the cause of mortality in amphibians infected with $B$. dendrobatidis have been suggested. The first is that $B$. dendrobatidis disrupts osmoregulation in the skin of infected amphibians, and the second is that $B$. dendrobatidis produces a toxin that affects organs (Berger et al. 1998, 2007, Blaustein et al. 2005). These hypotheses are not necessarily mutually exclusive. However, no study has provided data to determine if either or both hypotheses are correct. 
Amphibian skin is well studied due to its unique functions (Deyrup 1964, Heatwole \& Barthalmus 1994, Jorgensen 1997). The integument is a site of regulated transport for water, ions (electrolytes) and respiratory gases (Deyrup 1964, Heatwole \& Barthalmus 1994, Jorgensen 1997). Permeability of frog skin varies over the body surface of an individual and also among species (Deyrup 1964, Heatwole \& Barthalmus 1994). In some species osmotic permeability is greatest in an area of ventral integument commonly referred to as the pelvic patch (Czopek 1965, Baldwin 1974, Word \& Hillman 2005), where there is dense cutaneous vasculature (Czopek 1965). Concomitantly, Batrachochytrium dendrobatidis occurs more commonly and at higher density in the ventral integument of infected frogs (Berger et al. 2005b, Puschendorf \& Bolaños 2006). B. dendrobatidis grows within the keratinized cells of the superficial epidermis and causes irregular skin sloughing, hyperplasia and hyperkeratosis (Berger et al. 1998, 2005b, 2007, Pessier et al. 1999). Other pathological changes including cytoplasmic degeneration and vacuolation in scattered cells have been observed by light and electron microscopy, but these changes are not usually severe (Berger et al. 2007). Thus, it is unclear how a superficial skin infection kills frogs.

The aim of this research was to investigate pathogenesis in amphibians with chytridiomycosis. We evaluated changes in physiological parameters after infection with Batrachochytrium dendrobatidis in the common green tree frog Litoria caerulea, a species known to be susceptible to infection (Berger et al. 2005a). We found severely diseased frogs had reduced blood plasma osmolality and electrolyte concentrations, indicating osmotic imbalance. Other biochemical and hematological parameters including plasma proteins, tissue enzymes and hematocrit were measured as markers of general health and did not vary significantly.

\section{MATERIALS AND METHODS}

Blood samples were collected twice over the course of infection during an outbreak in captive-bred Litoria caerulea. This outbreak was monitored by swabbing frogs every $10 \mathrm{~d}$ for $73 \mathrm{~d}$ for Batrachochytrium dendrobatidis zoospore equivalents, determined by real-time PCR analysis (Boyle et al. 2004). Together with clinical signs of disease, most of which are apparent only in the few days before death (Berger et al. 2007), these PCR results were used as indicators of severity of infection (Fig. 1). Blood was collected for hematology and plasma biochemistry before and after frogs became diseased.

Frogs were housed individually at 18 to $23^{\circ} \mathrm{C}$ and fed vitamin-dusted crickets. Ten Litoria caerulea became

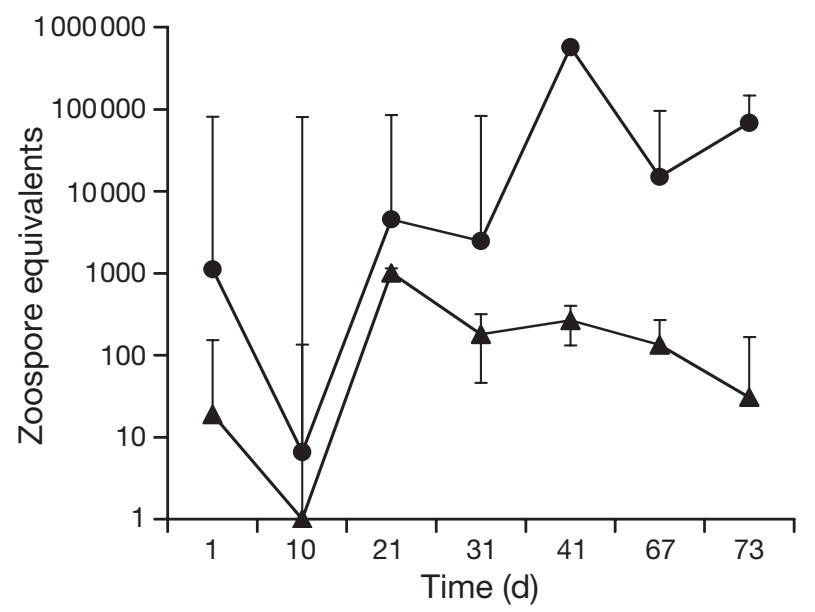

Fig. 1. Litoria caerulea infected with Batrachochytrium dendrobatidis. Zoospore equivalents over time in severely diseased $(\bullet)(n=7)$ and aclinical $(\boldsymbol{\Lambda})(\mathrm{n}=3)$ frogs. Uninfected amphibians (with zero zoospores) are not shown. Results are from real-time PCR on skin swabs

infected, and 2 were uninfected. Within $16 \mathrm{~d}$ after suspected exposure, blood $(<1 \%$ frog weight) was collected with a heparinized syringe and needle via the ventral abdominal vein or heart after anesthesia by shallow immersion in a solution bath of $0.1 \%$ MS222 (tricaine methanesulfonate, Sigma Chemical). MS222 does not kill Batrachochytrium dendrobatidis (Webb et al. 2005). A sample of whole blood was analyzed (Bayer 865 rapidlab blood gas analyzer) for electrolyte concentrations, $\mathrm{pH}$ and carbon dioxide. Hemoglobin was measured using the modified Drabkin's method. Total red cells were counted using a modified Neubauer hemocytometer with NatHerrick's solution as the diluent. Plasma osmolality was measured using a Knauer automatic osmometer with $400 \mathrm{mmol}^{-1}$ standards.

Litoria caerulea were monitored daily for clinical signs of chytridiomycosis including lethargy, inappetance, decreased respiration rate, cutaneous erythema, irregular skin sloughing and abnormal posture (legs splayed out posteriorly). A second blood sample was collected immediately before euthanasia for 7 infected $L$. caerulea when they showed obvious clinical signs between 53 and $73 \mathrm{~d}$ post-exposure (Days 53, 56, 59, 59, 59, 60, 72) and for 3 infected and 2 uninfected frogs that were clinically normal (Days 72 to 74). Samples were tested by blood gas analysis as previously described. A large range of blood biochemical parameters was measured to evaluate functioning of, or damage to, organs including liver, kidney muscle and pancreas. For this, plasma was analyzed for 16 biochemical parameters (amylase, lactate, aspartate, aminotransferase, creatine kinase, glutamate dehydrogenase, hemoglobin, platelets, hematocrit, albumin, 
bile acids, cholesterol, glucose, globulin, total protein and urea) (Olympus AU400 at 37C at IDEXX Laboratories, Brisbane).

These methods were performed with James Cook University Animal Ethics Committee approval (Permit No. A593). All data were analyzed using SPSS statistics, Version 12.0. Data sets were tested for normality and homogeneity of variance (homoscedasticity), and non-parametric instead of parametric tests were used when violations of assumptions occurred.

\section{RESULTS}

Skin swab samples collected on the date of death in diseased frogs $(n=7)$ and at the termination of the experiment in aclinically infected amphibians $(n=3)$ indicated Batrachochytrium dendrobatidis zoospore equivalents were greater in severely diseased amphibians (Mann-Whitney test, $\mathrm{p}=0.017$ ). Swabs from uninfected amphibians $(\mathrm{n}=2)$ were negative. There were no significant differences in blood test results between frogs that were uninfected and frogs that were infected but aclinical. However, amphibians with severe clinical signs of disease had significantly reduced plasma osmolality compared with both uninfected and aclinical groups combined (Table 1). Further, severely diseased frogs had significant reductions in plasma sodium, potassium, chloride and magnesium concentrations (Table 1). None of the other 16 biochemical parameters (listed in 'Materials and methods') varied significantly (Table 1).

In addition to comparing results among groups of amphibians with different severities of disease, we evaluated the changes in a range of biochemical parameters within individual Litoria caerulea as infections progressed. Significant biochemical changes occurred solely in amphibians that developed severe disease. Plasma concentrations of sodium, potassium, chloride and blood $\mathrm{pH}$ in severely diseased amphibians were

Table 1. Litoria caerulea infected with Batrachochytrium dendrobatidis. Biochemical and hematological parameters. Designation of aclinically infected/uninfected or severely infected was determined by clinical signs and by measuring the number of zoospor equivalents by real-time PCR. Uninfected frogs were grouped with the aclinical frogs because there were no significant differences between the 2 groups. AST: aspartate aminotransferase; GLDH: glutamate dehydrogenase; RBC: red blood cell; PCV: packed cell volume. ${ }^{*}$ Significant at $\mathrm{p}<0.05$

\begin{tabular}{|c|c|c|c|c|c|c|c|}
\hline \multirow{3}{*}{ Measured variables } & \multicolumn{6}{|c|}{ Infection status } & \multirow{3}{*}{ p-value } \\
\hline & \multicolumn{3}{|c|}{ Uninfected/aclinical } & \multicolumn{3}{|c|}{ Clinical } & \\
\hline & Mean & $\mathrm{SD}$ & $\mathrm{N}$ & Mean & $\mathrm{SD}$ & $\mathrm{N}$ & \\
\hline Mass (g) & 50.52 & 16.1 & 5 & 35.7 & 5.3 & 7 & 0.109 \\
\hline \multicolumn{8}{|l|}{ Electrolyte concentrations } \\
\hline Osmolality $\left(\mathrm{mmol} \mathrm{l}^{-1}\right)$ & 217.2 & 28.5 & 5 & 153.5 & 46.6 & 6 & $0.026^{*}$ \\
\hline Sodium $\left(\mathrm{mmol} \mathrm{l}^{-1}\right)$ & 102.8 & 7.9 & 5 & 74.4 & 9.5 & 7 & $0.001^{*}$ \\
\hline Potassium $\left(\mathrm{mmol} \mathrm{l}^{-1}\right)$ & 2.74 & 0.3 & 5 & 1.5 & 0.8 & 7 & $0.016^{*}$ \\
\hline Magnesium (mmol l-1) & 0.98 & 0.4 & 5 & 0.3 & 0.2 & 7 & $0.027^{*}$ \\
\hline Chloride $\left(\mathrm{mmol} \mathrm{l}^{-1}\right)$ & 79 & 7.5 & 5 & 47.3 & 9.4 & 7 & $0.001^{*}$ \\
\hline Sodium:potassium ratio & 32.52 & 3.5 & 5 & 30.2 & 6.6 & 6 & 0.491 \\
\hline \multicolumn{8}{|l|}{ Blood gases } \\
\hline $\mathrm{CO}_{2}\left(\mathrm{pCO}_{2} \mathrm{mmHg}\right)$ & 35.54 & 12.2 & 5 & 25.3 & 9.7 & 6 & 0.153 \\
\hline $\mathrm{pH}$ & 7.31 & 0.1 & 5 & 7.2 & 0.2 & 7 & 0.369 \\
\hline \multicolumn{8}{|l|}{ Enzymes/Markers } \\
\hline Amylase $\left(\mathrm{IU} \mathrm{l}^{-1}\right)$ & 3100.6 & 948 & 5 & 3482.4 & 1517.5 & 5 & 0.646 \\
\hline AST (IU l $\left.{ }^{-1}\right)$ & 368 & 194.5 & 5 & 1003.3 & 895.2 & 7 & 0.154 \\
\hline GLDH $\left(\mathrm{IU} \mathrm{l}^{-1}\right)$ & 12 & 4.8 & 5 & 31.7 & 30 & 7 & 0.181 \\
\hline Creatine kinase (IU l ${ }^{-1}$ ) & 1627.8 & 895.6 & 5 & 2782.4 & 2524.1 & 7 & 0.356 \\
\hline \multicolumn{8}{|l|}{ Hematology } \\
\hline $\mathrm{RBC}\left(\times 10^{12} \mathrm{l}^{-1}\right)$ & 0.42 & 0.96 & 5 & 0.52 & 0.17 & 6 & 0.291 \\
\hline Hemoglobin $\left(\mathrm{g} \mathrm{l}^{-1}\right)$ & 0.163 & 0 & 5 & 0.2 & 0.1 & 6 & 0.704 \\
\hline Platelets & 8680.2 & 5220.2 & 5 & 6523 & 3158.7 & 6 & 0.418 \\
\hline PCV (\%) & 22.8 & 5.6 & 5 & 26.5 & 7.1 & 6 & 0.371 \\
\hline \multicolumn{8}{|l|}{ Other blood constituents } \\
\hline Albumin $\left(\mathrm{g} \mathrm{l}^{-1}\right)$ & 26.6 & 5.4 & 5 & 30.1 & 3.9 & 7 & 0.212 \\
\hline Bile acids $\left(\mu \mathrm{mol} \mathrm{l}^{-1}\right)$ & 7 & 8.5 & 5 & 35.7 & 41.1 & 7 & 0.160 \\
\hline Cholesterol $\left(\mathrm{mmol} \mathrm{l}^{-1}\right)$ & 1.4 & 0.9 & 5 & 2 & 2.3 & 5 & 0.630 \\
\hline Glucose $\left(\mathrm{mmol} \mathrm{l}^{-1}\right)$ & 3.62 & 1.1 & 5 & 3.6 & 2.1 & 3 & 0.964 \\
\hline Globulin $\left(\mathrm{g}^{-1}\right)$ & 17.2 & 3.7 & 5 & 26.7 & 9.8 & 7 & 0.068 \\
\hline Total protein $\left(\mathrm{g} \mathrm{l}^{-1}\right)$ & 43.8 & 8.7 & 5 & 56.9 & 12.9 & 7 & 0.079 \\
\hline Urea $\left(\mathrm{mmol} \mathrm{l} \mathrm{l}^{-1}\right)$ & 9.02 & 2.4 & 5 & 11.5 & 8.1 & 7 & 0.531 \\
\hline
\end{tabular}



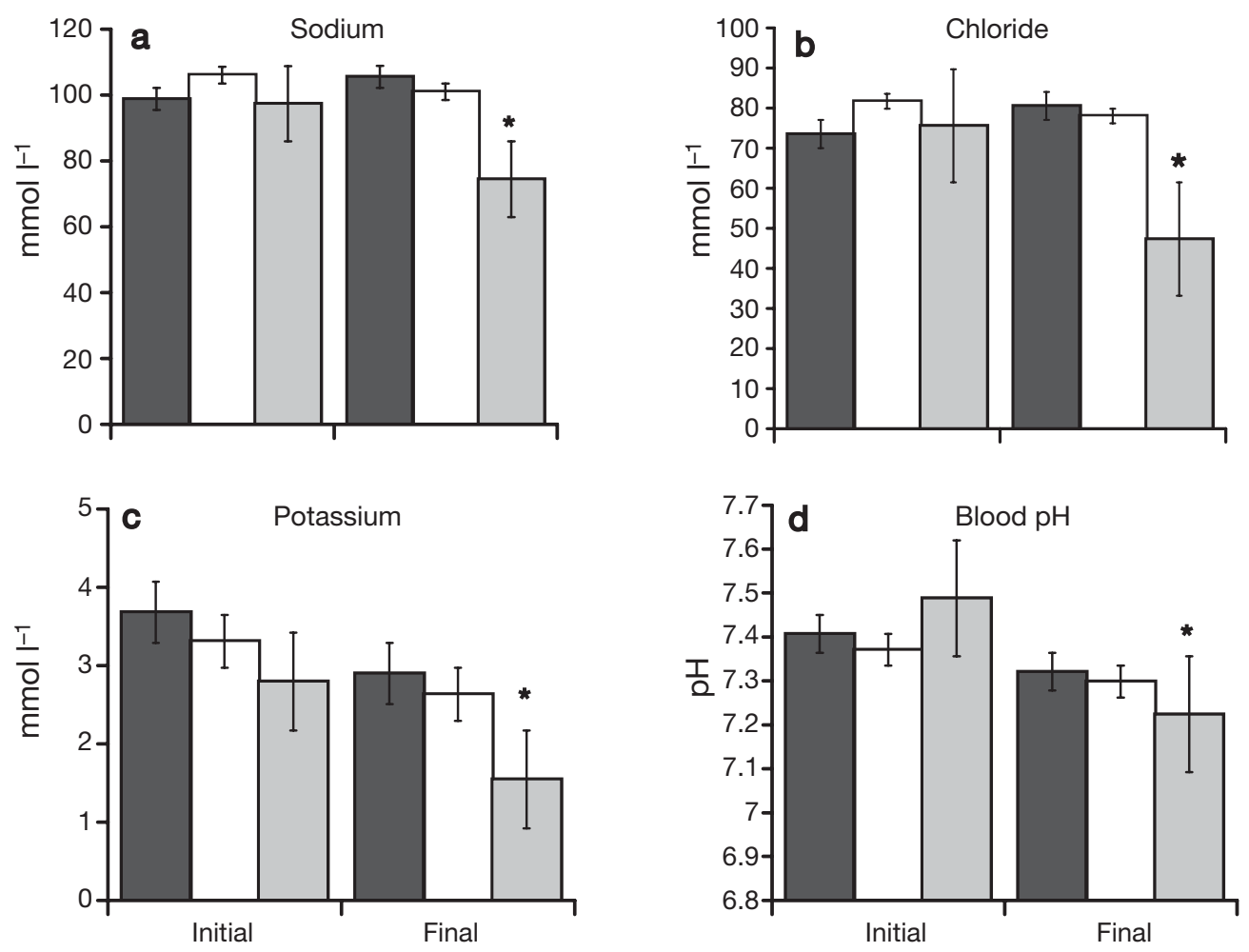

Fig. 2. Litoria caerulea infected with Batrachochytrium dendrobatidis. Changes in $(\mathrm{a}-\mathrm{c})$ electrolyte concentrations and (d) blood $\mathrm{pH}$ between initial and final blood samples of frogs. Bar graphs show mean values ( \pm SEM). Uninfected individuals are separated from aclinically infected individuals. (a-c) Plasma electrolyte concentrations or (d) bloood pH were reduced in final blood samples from severely diseased (light grey bars, $n=7$ ), but not in aclinically infected (white bars, $\mathrm{n}=3$ ) or uninfected (dark grey bars, $\mathrm{n}=2$ ) frogs (paired $t$-test). ${ }^{*}$ Significant at $(\mathrm{a}, \mathrm{b}) \mathrm{p}<0.001$; (c) $\mathrm{p}=0.036$; (d) $\mathrm{p}=0.006$

significantly decreased in final blood samples compared with initial blood samples (Fig. 2). None of these changes were detected in aclinically infected or uninfected amphibians (Fig. 2). Furthermore, no other measured parameter (carbon dioxide, glucose, red cell count, hematocrit and hemoglobin) varied significantly in any group over time.

\section{DISCUSSION}

We provide evidence that severe chytridiomycosis causes decreases in blood $\mathrm{pH}$, plasma osmolality and plasma sodium, potassium, magnesium and chloride concentrations. Reduction in electrolyte concentrations could occur if electrolytes were diluted due to increased water uptake or if there was an overall loss from the blood. We found no significant change from initial to final measurements in body mass, hematocrit, albumin, or urea, indicating that hydration status is probably unaffected in severely diseased frogs. Therefore, it appears that the reductions in electrolyte concentrations were due to depletion from circulation rather than water uptake. The disproportionate loss of electrolytes compared with water signifies an imbalance in osmotic homeostasis.

Osmotic balance in amphibians is complex because there are multiple sites of regulation (Deyrup 1964, Heatwole \& Barthalmus 1994, Jorgensen 1997). Amphibian skin is one site of regulation, and is critical to water and electrolyte homeostasis (Deyrup 1964, Heatwole \& Barthalmus 1994, Jorgensen 1997). Water flow results when an osmotic gradient is established by an exchange of electrolytes across the integument (Ussing \& Zerahn 1951, Deyrup 1964, Heatwole \& Barthalmus 1994, Jorgensen 1997). This tightly regulated transport is influenced not only by the salinity of the external aquatic environment, but also by plasma osmolality (Parsons et al. 1990) and skin circulation (Heatwole \& Barthalmus 1994). Thus, cutaneous osmoregulation and plasma osmolality are linked. Further, damage to amphibian skin can lead to fatal electrolyte imbalances (Wright \& Whitaker 2001). We suggest that Batrachochytrium dendrobatidis disrupts normal cutaneous transport, possibly through the alteration of electrolyte channels, leading to electrolyte loss and osmotic imbalance in diseased amphibians. 
Pathogens are known to compromise function in other epithelia such as mammalian trachea and intestine (Berkes et al. 2003, Kunzelmann \& McMorran 2006). Electrolyte transport is disrupted by pathogen adhesion to protein-based receptors (Cameron \& Douglas 1996, Berkes et al. 2003, Kunzelmann \& McMorran 2006) or by pathogen-secreted toxins that alter cell function (Berkes et al. 2003, Kunzelmann \& McMorran 2006). For example, sodium transport and fluid balance were disrupted when a viral pathogen was introduced to mouse tracheal epithelium (Kunzelmann et al. 2000). This resulted from a down-regulation of amiloridesensitive sodium channels in the apical membranes of the epithelium (Kunzelmann et al. 2000). It is possible that Batrachochytrium dendrobatidis disrupts sodium channels by a comparable mechanism. The selective barrier properties of frog skin are primarily determined by electrolyte transport in the mitochondrial-rich cells of the stratum granulosum (Ehrenfeld \& Klein 1997), where $B$. dendrobatidis is found in severe infections (Berger et al. 1998). This hypothesis is further supported by Ussing chamber tests (Ussing \& Zerahn 1951) using skin samples from infected Bufo woodhousii, which showed that active sodium transport was reduced in diseased toads under short-circuit conditions (Voyles et al. 2005). However, these results did not clarify if the loss of sodium and other electrolytes could occur via the skin or other excretion pathways. More specific tests investigating disruption of electrolyte transport are underway.

Although our results do not detail the exact mechanism by which Batrachochytrium dendrobatidis disrupts epidermal functioning, the severe reduction in plasma electrolytes is a plausible cause of mortality. Reduced plasma osmolality and reduced plasma electrolyte concentrations, particularly hyponatremia (low sodium) and hypokalemia (low potassium), are potentially life-threatening conditions because these electrolytes are crucial in cell membrane function. In addition, sodium and potassium facilitate the conduction of action potentials in smooth and cardiac muscle and are important in multiple physiological processes.

The 3 Litoria caerulea that appeared healthy despite infection had no significant changes in plasma osmolality or electrolyte concentrations. These results suggest that electrolyte reductions occur only in terminal stages of infection and may account for the neurological signs such as muscle tetany that precede death (Berger et al. 2007). While most amphibians can tolerate changes in plasma electrolyte levels (Deyrup 1964), the observed decrease of approximately $30 \%$ plasma sodium and $50 \%$ plasma potassium concentrations in diseased frogs may be too extreme. Additional research is needed to resolve whether these conditions lead to death through cardiac arrhythmia, myocardial failure, organ failure, or a combination of these and other factors.
Determining how Batrachochytrium dendrobatidis kills amphibians is essential to understanding the biology of chytridiomycosis. Additionally, research on the mechanisms of pathogenesis may explain why there is interspecific variation in susceptibility to the disease, a key question for amphibian conservation. Resolving the pathophysiological effects will provide crucial information for researchers, wildlife managers and veterinary clinicians in treating captive frogs and facilitating the recovery of wild frog populations that are currently affected by the disease.

Acknowledgements. We thank N. Sullivan for advice on plasma biochemistry, B. Pederson for research assistance and L. J. Livo for continual support. The Australian Research Council and the Australian Department of Environment and Heritage funded this research.

\section{LITERATURE CITED}

Baldwin RA (1974) The water balance response of the pelvic 'patch' of Bufo punctatus and Bufo boreas. Comp Biochem Physiol A 47:1285-1295

Berger L, Spear R, Daszak PD, Green ED and 10 others (1998) Chytridiomycosis causes amphibian mortality associated with population declines in the rain forests of Australia and Central America. Proc Natl Acad Sci USA 95:9031-9036

Berger L, Marantelli G, Skerratt LF, Speare R (2005a) Virulence of the amphibian chytrid fungus Batrachochytrium dendrobatidis varies with the strain. Dis Aquat Org 68:47-50

Berger L, Speare R, Skerratt LF (2005b) Distribution of Batrachochytrium dendrobatidis and pathology in the skin of green tree frogs Litoria caerulea with severe chytridiomycosis. Dis Aquat Org 68:65-70

Berger L, Longcore JE, Speare R, Hyatt A, Skerratt LF (2007) Fungal diseases of amphibians. In: Heatwole $\mathrm{H}$, Wilkinson J (eds) Amphibian biology: conservation and decline, Vol 8. Surrey Beatty \& Sons, Chipping Norton (in press)

Berkes J, Viswanathan VK, Savkovic SD, Hecht G (2003) Intestinal epithelial responses to enteric pathogens: effects on the tight junction barrier, ion transport, and inflammation. Gut 52:439-451

Blaustein AR, Romansic JM, Scheessele EA, Han BA, Pessier AP, Longcore JE (2005) Interspecific variation in susceptibility of frog tadpoles to the pathogenic fungus Batrachochytrium dendrobatidis. Conserv Biol 19:1460-1468

Boyle DG, Boyle DB, Olsen, V, Morgan JAT, Hyatt AD (2004) Rapid quantitative detection of chytridiomycosis (Batrachochytrium dendrobatidis) in amphibian samples using real-time Taqman PCR assay. Dis Aquat Org 60:141-148

Cameron BJ, Douglas LJ (1996) Blood group glycolipids as epithelial cell receptors for Candida albicans. Infect Immun 64:891-896

Czopek J (1965) Quantitative studies on the morphology of respiratory surfaces in amphibians. Acta Anat 62:296-323

Deyrup IJ (1964) Water balance and kidney. In: Moore JA (ed) Physiology of the amphibia. Academic Press, New York, p 251-328

Ehrenfeld J, Klein U (1997) The key role of the $\mathrm{H}^{+} \mathrm{V}$-ATPase in acid-base balance and $\mathrm{Na}^{+}$transport processes in frog skin. J Exp Biol 200:247-256

Heatwole H, Barthalamus GT (1994) Amphibian biology: the integument. Surrey Beatty \& Sons, Chipping Norton 
Jorgensen CB (1997) 200 years of amphibian water economy: from Robert Townson to the present. Biol Rev Camb Philos Soc 72:153-237

Kunzelmann K, McMorran B (2006) First encounter: how pathogens compromise epithelial transport. Physiologia 19:240-244

Kunzelmann K, Beesley AH, King NJ, Karupiah G, Young JA, Cook DI (2000) Influenza virus inhibits amiloride-sensitive $\mathrm{Na}^{+}$channels in respiratory epithelia. Proc Natl Acad Sci 97:10282-10287

Lips KR, Brem F, Brenes R, Reeve JD and 6 others (2006) Emerging infectious disease and the loss of biodiversity in a Neotropical amphibian community. Proc Natl Acad Sci USA 103:3165-3170

Longcore JE, Pessier AP, Nichols DK (1999) Batrachochytrium dendrobatidis gen et sp nov, a chytrid pathogenic to amphibians. Mycologia 91:219-227

Nichols DK, Lamirande EW, Pessier AP, Longcore JE (2001) Experimental transmission of cutaneous chytridiomycosis in dendrobatid frogs. J Wildl Dis 37:1-11

Parsons RH, Thorn LM, Salerno SM, Petronis S (1990) Saltload effects on osmotic water flow, tritiated water diffusion, and the cardiovascular system in Rana pipians and Rana catesbeiana. Physiol Zool 63 (3):571-586

Pessier AP, Nichols DK, Longcore JE, Fuller MS (1999) Cutaneous chytridiomycosis in poison dart frogs (Dendrobates spp.) and White's tree frogs (Litoria caerulea). J Vet Diag Invest 11:194-199

Editorial responsibility: Alex Hyatt, Geelong, Victoria, Australia
Puschendorf R, Bolaños F (2006) Detection of Batrachochytrium dendrobatidis in Eleutherodactylus fitzingeri: effects of skin sample location and histologic stain. J Wildl Dis 42:301-306

Stuart SN, Chanson JS, Cox NA, Young BE, Rodrigues ASL, Fischman DL, Walker RW (2004) Status and trends of amphibian declines and extinctions worldwide. Science 306:1783-1786

Ussing HH, Zerahn K (1951) Active transport of sodium as the source of electric current in the short-circuited isolated frog skin. Acta Physiol Scand 23:110-127

Voyles J, Carey C, Livo LJ (2005) Evidence of osmotic and ionic disruption in amphibians infected with Batrachochytrium dendrobatidis. In: Donnelly $M$ (ed) A new generation of research in amphibian declines. Proc 85th Am Soc Herp Ich Symp USA. American Society of Ichthyologists and Herpetologists, Lawrence, KS. Also available at: www.asih.org/2005abstracts

Webb R, Berger L, Mendez D, Speare R (2005) MS-222 (tricaine methane sulfonate) does not ill the amphibian chytrid fungus Batrachochytrium dendrobatidis. Dis Aquat Org 68:89-90

Word JM, Hillman SS (2005) Osmotically absorbed water preferentially enters the cutaneous capillaries of the pelvic patch in the toad Bufo marinus. Physiol Biochem Zool 78:40-47

Wright KM, Whitaker BR (2001) Pharmacotherapeutics. In: Amphibian medicine and captive husbandry. Krieger Publishing, Malabar, FL, p 318-319

Submitted: January 29, 2007; Accepted: June 11, 2007

Proofs received from author(s): August 27, 2007 